\title{
AN EMPIRICAL EXAMINATION OF PROJECT LEADERSHIP STYLE IN AN INFORMATION SYSTEMS ENVIRONMENT
}

\author{
Mohan Thite and Pamela Simmons \\ Swinburne University of Technology \\ PO Box 218, Haw thorn- 3122 \\ Melbourne, Australia \\ Email: Mthite@swin.edu.au; Psimmons@swin.edu.au
}

\begin{abstract}
After establishing that leadership is one of the critical success factors in IS projects with the support of literature, this study examines the most appropriate leadership style at the project management level for the successful execution of IS projects. The suitability of Transformational Leadership style in an IS project environment is tested in a survey of Australian IS projects. The leadership behaviour of more and less successful IS project managers as perceived by themselves and their subordinates is analysed in conjunction with other contingency factors influencing project implementation. The results support the proposition that there is a difference in the leadership styles of more and less successful project managers as perceived by their subordinates and that the successful managers exhibit significantly more of Transformational leadership characteristics.
\end{abstract}

\section{INTRODUCTION}

There is a widespread dissatisfaction about the performance of Information Systems (IS) projects. Inordinate delays, excessive budget over-runs, post-implementation testing, user dissatisfaction, late deliveries, poor reliability, maintenance problems... the list of woes continues (Kapur, 1989; AbdelHamid, 1990). Considering the critical importance of IS, the failure rate is quite disturbing.

Researchers have endeavoured to explain the causes of IS project failure. Significant efforts have been made to identify critical success factors so that IS developers can focus their attention on these factors to ensure success. Research has established that when it comes to project management, technology is more often a secondary issue behind management, particularly of human resources (Sauer, 1993).

Leadership is critical in any human endeavour. It is generally recognised that technical/scientific professionals lack managerial skills, including leadership skills. Many project managers are perceived as having average or less than average managerial skills (Anderson, 1992). In a job satisfaction survey of IS professionals, poor management was the most commonly cited source of frustration for IS employees (Kapur, 1989). Pulk (1990) opines that the most obvious cause of the increased cost (of software development) is the lack of effective leadership within software development projects. Therefore, it is important to look at the leadership behaviour of IS project managers as a critical success factor.

This study aims at finding a suitable leadership style that would make a significant contribution to the success of IS projects. Transformational leadership is a new paradigm in leadership research. Bass \& Avolio (1991) have made a seminal contribution to the research on transformational leadership and this study tests their model in an IS environment to examine whether it adequately differentiates between successful and unsuccessful projects and whether more successful project managers exhibit more of transformational leadership characteristics than their less successful counterparts.

\section{CRITICAL SUCCESS FACTORS}

There does not appear to be a consensus of opinion on the criteria for judging project success and the factors that influence that success (Wateridge, 1995). Pinto \& Slevin (1987:3) presented a comparative analysis of various studies and identified the following nine critical success factors in these studies on project implementation: clearly defined goals; competent project manager; top management support; competent project team members; sufficient resource allocation; adequate communication channels; control mechanisms; feedback capabilities; and responsiveness to clients. They empirically developed a framework of the project implementation process and a diagnostic instrument called the Project Implementation Profile (PIP) which identifies ten critical factors: project mission; top management support; project schedule/plan; client consultation; personnel; technical tasks; client acceptance; monitoring \& feedback; communication; and trouble shooting. However, Pinto \& Prescott (1988) found out in another study that the relative importance of various critical success factors are subject to change at different phases of the project implementation process.

According to Wateridge (1995), within the IS domain there has been little research and testing of project-success criteria and his research pointed out that there is a vast difference between the perceptions of users and those of project managers on the factors that contribute to successful IS projects. Deutsch (1991), through an exploratory analysis relating to the software project management, 
derived that the "residual management power factors", such as management of business risk, technical risk, external interface, multiple user needs, problem scope and planning \& feedback correlate to successful project outcomes.

Brown (1994) identified organisational commitment, complete functional design and competent project management as critical success factors for large IS projects. Cash \& Fox (1992) opine that management's involvement, leadership, staffing and control \& reporting are elements often found in successful implementation of computer systems.

\section{LEADERSHIP IN IS PROJECTS}

The literature on IS project management provides ample evidence on the importance of non-technical issues as critical success factors (Phan et al., 1988; Laudon \& Laudon, 1990). Although there is a paucity of empirical evidence on the causes for project failure, Sauer (1993) suggests that a consensus has been reached amongst researchers that failure is generally caused by the neglect of the behavioural and social factors. The role of the project manager in IS projects is therefore even more challenging and vital than in other types of projects where these issues arc less critical.

Leadership taken in the context of projects presents special challenges (Cleland, 1995: 86). In IS departments, project managers are faced with increasingly complex tasks which require more than a single set of management skills (Carter, 1988). That is why, the concept of "Hybrid" managers, particularly in the context of IS environment is gaining prominence (Palmer \& Ottley, 1990).

Successful projects almost always have a "champion" who either by past experience or by persistent determination provides needed leadership to members of the project team to see that results are achieved (Cash \& Fox, 1992). A project's success or failure is the result of the leadership of the project's stakeholders (Cleland, 1995: 85). Bridging the gap between software and product development requires effective leadership and project management within the software design teams (Pulk, 1990).

The key ingredient to effective project management is good people management and leadership skills. The more complex the people situation, the more critical a project manager's leadership capabilities become (Bates, 1994). In today's corporations, tremendous responsibility lies with the IS project manager, who must take the corporation's vision and translate that vision in to systems that support the company's strategic direction (Geaney, 1995).

\section{TECHNICAL LEADERSHIP SKILLS}

Compared to other occupational groups, the management and leadership of technical employees pose unique challenges (Thite, 1997). Leading achievement-oriented technical professionals in a turbulent business environment requires non-traditional leadership skills and styles.

Weinberg (1986), an acknowledged expert on technical leadership, opines that outstanding technical leaders exhibit the problem-solving leadership style by concentrating on three major areas: understanding the problem, managing the flow of ideas, and maintaining quality. A study by Rosenbaum (1991) found many common patterns related to effective technical leadership. Successful leaders coach for peak performance, remove organisational obstructions from the path to innovation. orchestrate the professional development of their subordinates, expand individual productivity through team work, and facilitate self management. The study concluded that technical leaders in a hightechnology world need to be "High-touch", that is, adept at communicating, influencing and motivating. Within the IS environment, several studies have highlighted the essential qualities and skills of IS project managers to ensure success. Table-1 gives a comparative picture of such studies. They highlight the importance of IS manager's ability to manage people, technology, stress, emotions, organisational politics and obstacles, communication etc.

\section{Table-1: Essential qualities and skills of IS project managers}

\begin{tabular}{|l|l|}
\hline Rahn, 1987 & $\begin{array}{l}\text { Willingness to take risks, Willingness to commit time, Ability to handle stress } \\
\text { well, Deposition to people management, Right emotional disposition, } \\
\text { Communication skills, Ability to handle politics }\end{array}$ \\
\hline Bander, 1986 & $\begin{array}{l}\text { Problem solving, Managerial identity, Achievement orientation, Strong } \\
\text { influence }\end{array}$ \\
\hline Geaney, 1995 & $\begin{array}{l}\text { Visible leadership, Flexibility, Sound business judgement, Trust worthiness, } \\
\text { Active listening skills }\end{array}$ \\
\hline Bloom, 1996 & $\begin{array}{l}\text { Technical competence, Political \& people skills, Handle obstacles, Maturity to } \\
\text { accept full project responsibility, Stamina \& sense of humour }\end{array}$ \\
\hline
\end{tabular}




\section{TRANSFORMATIONAL LEADERSHIP}

The concept of leadership can be traced back to antiquity and is, in a sense, terra incognita (unknown territory). Today's new ideas about leadership are testing and threatening many of our traditional notions of what leaders do (Cleland, 1995).

Transformational leadership, transactional leadership, and laissez-faire form a new paradigm for understanding both the lower- and higher-order effects of leadership (Bass and Avolio, 1989:1). Earlier leadership theories confined themselves to transactions based on initiation (task orientation) and consideration (people orientation) which were not sufficient to explain the full range of leadership behaviours commonly associated with the best and also the worst leaders (Bass \& Avolio, 1993).

Bass (1985) described transformational leaders as those who:

- Raise followers' level of awareness of the importance of achieving valued outcomes and the strategies for reaching them.

- Encourage followers to transcend their own self-interest for the sake of the team, organisation, or larger policy.

- Develop followers' needs to higher levels in such areas as achievement, autonomy, and affiliation, which can be both work-related and non work-related.

According to Bass \& Avolio (1993), transformational leaders exhibit the following key leadership behaviours:

1. Charisma: Followers identify with and emulate these leaders, who are trusted and seen as having an attainable mission \& vision. This is further subdivided in to Attributed Charisma \& Idealised Influence. Sample item: Instils pride in being associated with him/her.

2. Inspirational motivation: Provides symbols \& simplified emotional appeals to increase awareness and understanding of mutually desired goals. Sample item: Articulates a compelling vision of the future.

3. Intellectual stimulation: Encourages followers to question their own way of doing things or to break with the past. Sample item: Seeks differing perspectives when solving problems.

4. Individualised consideration: Followers are treated differently but equitably on a one-toone basis. Sample item: Spends time teaching and coaching.

Transactional leaders motivate followers by appealing to their self-interest and exert influence based on bureaucratic authority, rather than influence based on exchange or inspiration (Burns, 1978). According to Bass \& Avolio (1993), transactional leadership behaviour consists of:

1. Contingent reward: It involves a positively reinforcing interaction between leader \& follower that emphasises an exchange. The emphasis is on facilitating the achievement of objectives agreed to by followers. Sample item: Makes clear what one can expect to receive when performance goals are achieved.

2. Management-by-exception (MBE): Only when things go wrong will the leader intervene to make some correction. Punishment and discipline are likely to be evidence of such behaviour. Many studies have found that MBE can be split into an active and a passive factor. The active manager arranges to monitor and correct deviations (sample item: focuses attention on irregularities, mistakes, exceptions, and deviations from standards); the passive manager waits for them to occur before taking corrective action (sample item: shows that he/she is a firm believer in 'if it ain't brake, don't fix it').

Finally, Laissez-faire is a non-leadership behaviour where leadership is absent and any intervention is avoided. Bass and Avolio (1993) view transformational and transactional leadership as distinct but not mutually exclusive processes and the former can "augment" the effectiveness of the latter as illustrated in Figure-1. 
Figure-1: The Augmentation Model of Transactional and Transformational Leadership

TRANSFORMATIONAL LEADERSHIP

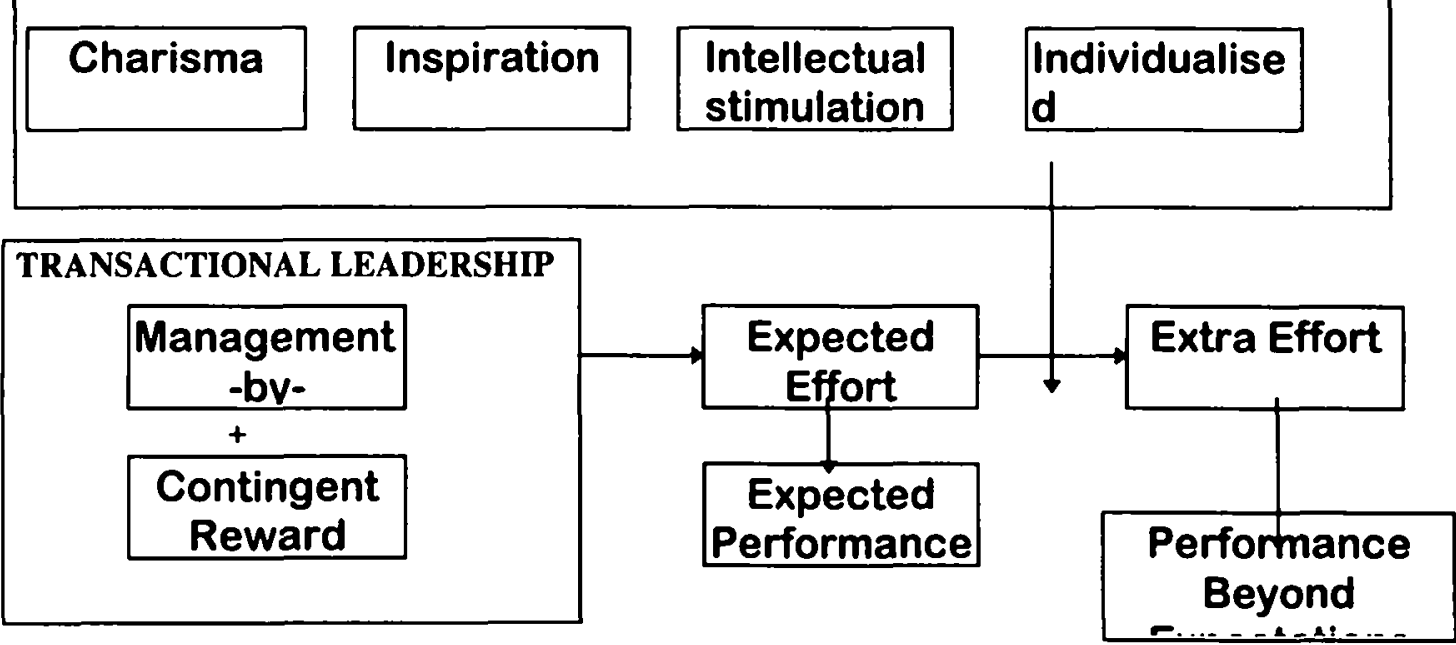

(Source: Bass \& Avolio, 1991)

The relevance of transformational leadership model in the technical/scientific fields has been empirically tested by several studies (Keller, 1995 \& 1992; Howell \& Higgins, 1990; Beatty \& Lee, 1992). It is also said to be effective in a team environment (Atwater and Bass, 1994). The model has been empirically validated in an Australian setting in hospital \& educational institutions(Parry \& Saros, 1994) and in the banking industry (Carless, 1995).

\section{RESEARCH ON IS PROJECT LEADERSHIP}

The authors tested the suitability of Transformational Leadership model in the Australian IS environment. The research examined whether the project managers of more successful IS projects exhibited more of Transformational leadership behaviour than Transactional leadership behaviour. The research was aimed at improving the quality of IS project management by focusing on project leadership in conjunction with other critical success factors.

\section{Sample Design}

The target population was IS companies and IS divisions of other companies in Australia which were engaged in software development activity in a project team environment. The list of organisations which were invited to participate in the survey was derived from a listing of top 50 software companies (Kennedy, 1996), selected listing of top 100 IT/IS using organisations (Conners, 1995), and selected member organisations of Australian Information Industry Association (AIIA). The survey was supported by the AIIA, the Australian Computer Society (ACS), the Australian Institute of Management (AIM).

As per the research design, a senior manager of the respondent company, to whom the IT Project Managers reported, selected two recent IT projects in his/her company to participate in the survey: one which was more successful in his/her opinion (in terms of technical quality, cost performance, deadlines, customer satisfaction, and overall project performance) and another which was less successful. Both these projects were at least half way through their duration (life cycle).

The sampling frame consisted of the IS project managers and their subordinates. The project manager indicated his/her leadership behaviour and its perceived effectiveness. The project team members also separately indicated the nature of the leadership behaviour of their Project Manager and their satisfaction with and the perceived effectiveness of the leadership style. 


\section{Research Instruments}

The Multi-factor Leadership Questionnaire (MLQ) (Form 5X) (Bass and Avolio, 1991) was used to examine leadership in this research. The questionnaire comprised seventy eight items that identify and measure key leadership behaviours. It assessed four transformational leadership factors (attributed charisma, idealised influence, intellectual stimulation and individualised consideration), three transactional leadership factors (contingent reward, management-by-exception: active and passive), and three outcome factors (satisfaction with the leader, individual and group effectiveness, and extra effort by followers).

Additional items (named as Technical factors) such as ability to fulfil subordinate's desire for autonomy, implement change, preventing organisational bureaucracy, encourage champions, facilitate career development etc. were added to the MLQ to specifically assess the leadership behaviours of IS managers and were derived from the meta analysis of the existing literature on technical leadership.

Leadership effectiveness was measured in two ways: one, by subordinate satisfaction ratings and two, by the project performance data provided by the senior manager of the participating organisations.

Apart from leadership, the study also examined other contingency factors which are critical to the success of IS projects. The Project Implementation Profile (PIP) (Slevin \& Pinto, 1986) was used to examine the contingency factors. The PIP identifies ten factors which are critical to the successful project implementation out of which three factors have been further identified as more critical than others in the "Execution Phase" of project life cycle in R\&D projects (including computer software and hardware development) (Pinto \& Slevin, 1989). These factors are: project mission, top management support and technical tasks. The survey respondents evaluated these factors with reference to their projects.

\section{Sample}

The research began in April, 1995. The survey questionnaires were posted between the period October 1995 to February 1996. In all, 158 organisations were invited to participate in the survey. However, 30 $(19 \%)$ organisations informed that they were not suitable, leaving a net total of 128 out of which 20 $(15.6 \%)$ refused to participate and $72(56.2 \%)$ did not respond at all.

Ultimately, 36 organisations participated in the survey yielding a net response rate of $28.1 \%$. Considering that $19 \%$ of organisations indicated their unsuitability for the survey, it is quite likely that many organisations which did not respond at all might have been unsuitable too and consequently, the response rate would have been higher. A higher response rate would have been preferred, however a response rate of $28 \%$ is reasonable, especially in light of the nature of the content of the questionnaire (Steeh, 1981) which specifically asked the organisations to identify and involve unsuccessful projects, a politically difficult task.

\section{Participant Profile}

Out of 36 organisations which participated in the survey, the data from one was unusable leaving 35 organisations comprising of 70 IS projects (equally divided between more and less successful projects), 70 project managers and 228 project team members. In terms of performance as measured by the senior managers of the organisations on a scale of 1 (low) to 5 (high), more successful projects had an average score of 4 while the unsuccessful ones scored 2 .

The participating organisations had a total of nearly 12,000 IS employees. On an average, each IS project covered comprised of seven members out of whom three participated in the survey. The average duration of these projects was 8 months. $74 \%$ of the participating project managers and $65 \%$ of project team members were male. $70 \%$ of project managers were at least graduates. There was not enough information available about the qualification of team members. Interestingly, both the managers and their subordinates had the same average IS experience (15 years) and had spent the same time, on an average, in their current projects (11 months).

\section{RESULTS}

Table- 2 shows the comparison of subordinates' ratings of project managers of more and less successful projects. The results show that the internal consistency (Cronbach alpha) values for all the scales are significant i.e. $>0.7$. Two-tail test of significance values (p) for all the scales are also significant, i.e. $<0.05$. These values indicate that there is a significant difference between the leadership styles, outcomes, and contingency scales between more and less successful projects, as predicted. 
Table- 2: Comparison of more and less successful projects: Subordinates' ratings of project managers on leadership, outcome \& contingency scales

(Scale: $1=$ High; 5 = Low $)$

\begin{tabular}{|c|c|c|c|c|c|c|c|c|}
\hline \multirow{2}{*}{$\begin{array}{l}\text { Scale } \\
\text { Transformational Factors }\end{array}$} & \multicolumn{2}{|c|}{$\begin{array}{l}\text { More successful } \\
\text { projects }\end{array}$} & \multicolumn{2}{|c|}{$\begin{array}{l}\text { Less successful } \\
\text { projects }\end{array}$} & \multirow[t]{2}{*}{ t-value } & \multirow[t]{2}{*}{ df } & \multirow[t]{2}{*}{$\begin{array}{l}\mathbf{p} \\
2 \text { tail } \\
\end{array}$} & \multirow[t]{2}{*}{$\alpha$} \\
\hline & Mean & SD & Mean & SD & & & & \\
\hline 1. Attributed Charisma & 18.27 & 6.38 & 21.77 & 6.95 & 2.83 & 226 & .005 & .86 \\
\hline 2. Idealised Influence & 22.91 & 7.97 & 27.44 & 9.64 & 3.88 & 226 & .000 & .89 \\
\hline 3. Intellectual Stimulation & 23.38 & 8.33 & 27.31 & 8.66 & 3.49 & 226 & .001 & .91 \\
\hline 4. Individualised Consdn. & 22.91 & 9.59 & 26.68 & 8.50 & 3.11 & 226 & .002 & $\overline{92}$ \\
\hline Total & 87.47 & 28.34 & 102.2 & 30.32 & 3.79 & 226 & .000 & \\
\hline \multicolumn{9}{|l|}{ Transactional Factors } \\
\hline 1. Contingent Reward & 24.84 & 9.87 & 28.23 & 9.33 & 2.64 & 225 & .009 & .88 \\
\hline 2. MBE- Active & 21.45 & 5.89 & 22.80 & 5.49 & 1.77 & 226 & $.078 \#$ & .70 \\
\hline 3. MBE-Passive & 25.56 & 6.36 & 23.49 & 7.17 & 2.28 & 210 & .023 & .88 \\
\hline & & & & & & & & \\
\hline Technical Leadership & 27.05 & 10.65 & 31.59 & 11.25 & 3.12 & 225 & .002 & .81 \\
\hline \multicolumn{9}{|l|}{ Outcome Factors } \\
\hline 1. Extra effort & 8.38 & 3.59 & 10.07 & 3.47 & 3.52 & 216 & .001 & .90 \\
\hline 2. Effectiveness & 9.03 & 2.79 & 11.06 & 3.11 & 5.19 & 225 & .000 & .86 \\
\hline 3. Satisfaction & 4.22 & 1.99 & 4.97 & 2.23 & 2.67 & 225 & .008 & .93 \\
\hline \multicolumn{9}{|l|}{ PIP } \\
\hline 1. Project Mission & 8.88 & 2.46 & 10.17 & 3.35 & 3.35 & 226 & .001 & .77 \\
\hline 2. Top Mangt. Support & 11.44 & 3.98 & 12.74 & 4.09 & 2.42 & 223 & .016 & .81 \\
\hline 3. Technical Tasks & 10.47 & 3.13 & 12.02 & 3.16 & 3.69 & 225 & .000 & .75 \\
\hline Total & 30.60 & 7.86 & 34.69 & 8.78 & 3.71 & 226 & .000 & \\
\hline
\end{tabular}

Notes:

$1 \mathrm{n}=$ For more successful projects, 123 subordinates \& 35 managers \& for less successful projects, 105 subordinates $\& 35$ managers.

\# Since the direction of research was specified, 1-Tail test of significance can be applied, the value of which is significant.

The scale for leadership, outcome and contingency factors was $1=$ high $\& 5=$ low which means lower the mean, higher the score. The mean scores for the transformational leadership scales, outcome scales, technical leadership scale and the contingency scales (PIP) for more successful projects are significantly lower than those of less successful projects. These results clearly indicate, as predicted, that in the opinion of the subordinates, the leadership behaviour of a more successful project manager is characterised more by transformational leadership qualities such as charisma, intellectual stimulation and individual consideration and such behaviour produces better outcomes in terms of extra effort, effectiveness and satisfaction. The success of such a leader is also attributable to other contingency factors covered by the study, viz., clear project mission, top management support and availability of required technology and expertise.

As regards transactional leadership scales, more successful project managers show less of managementby-exception (passive) behaviour (with higher mean scores) indicating in line with the model that MBE $(P)$ is the only negative leadership trait, whereas contingent reward and MBE (Active) are positive traits though not as effective as transformational leadership traits. The results reinforce the assertion made in the model that a leader who 'augments' his/her transactional behaviour with transformational behaviour tends to be more successful.

Table- 3 compares the leadership ratings with outcome ratings on their correlation co-efficient values (r). All scales of transformational leadership are significantly correlated with outcome scales, as predicted, indicating that subordinates are more satisfied with transformational leaders who encourage them to produce extra efforts and are more effective. Amongst transactional leadership scales, 
contingent reward is significantly correlated. However, MBE Active scale shows a weak correlation whilst MBE Passive shows strong but negative correlation, as predicted.

Based on the strength of correlation, the results indicate that in the opinion of the subordinates of more successful projects, the three most important leadership behaviours of their managers are: attributed charisma, individualised consideration and technical leadership. It is interesting to observe that for these subordinates, the contingent reward behaviour of their managers is more important than intellectual stimulation in terms of successful project outcome. The managers of more successful projects regard technical leadership as more important than transformational leadership in terms of the outcome of their leadership behaviour.

Table-3: Correlation Co-efficients: Comparison of Leadership ratings with outcome ratings

\begin{tabular}{|c|c|c|c|c|}
\hline Scale & \multicolumn{2}{|c|}{ More successful projects } & \multicolumn{2}{|c|}{ Less Successful projects } \\
\hline Transformational & $\begin{array}{l}\text { Subordinates' } \\
\text { Ratings }\end{array}$ & $\begin{array}{l}\text { Managers' (self) } \\
\text { Ratings }\end{array}$ & $\begin{array}{l}\text { Subordinates' } \\
\text { Ratings }\end{array}$ & $\begin{array}{l}\text { Managers' (self) } \\
\text { Ratings }\end{array}$ \\
\hline $\begin{array}{l}\text { Attributed } \\
\text { Charisma }\end{array}$ & .81 & .52 & .70 & .64 \\
\hline $\begin{array}{ll}2 . & \text { Idealised } \\
\text { Influence }\end{array}$ & .72 & .68 & .62 & .45 \\
\hline $\begin{array}{l}\text { Intellectual } \\
\text { stimulation }\end{array}$ & .63 & .54 & .58 & .39 \\
\hline $\begin{array}{ll}4 . & \begin{array}{l}\text { Individualised } \\
\text { consideration }\end{array} \\
\end{array}$ & .75 & .72 & .71 & .48 \\
\hline \multicolumn{5}{|l|}{ Transactional } \\
\hline $\begin{array}{l}\text { 1. } \begin{array}{l}\text { Contingent } \\
\text { reward }\end{array} \\
\end{array}$ & .71 & .37 & .66 & .63 \\
\hline 2. MBE Active & .48 & $.00 *$ & $-.00 *$ & .29 \\
\hline 3. MBE Passive & -.29 & -.33 & -.63 & -.44 \\
\hline Technical Leadership & .74 & .78 & .56 & .48 \\
\hline
\end{tabular}

Notes:

$1 \mathrm{n}=$ For more successful projects, 123 subordinates \& 35 managers \& for less successful projects, 105 subordinates \& 35 managers.

2 Considering the sample, $r$ values $>.19$ are considered significant

3 All the correlations are significant beyond the .000 level, except those marked with the asterix.

4 The sub-scales of Outcome scale are: Extra effort, Satisfaction and Effectiveness.

The results of the maximum likelihood factor analysis with varimax rotation show that some of the transformational leadership scales (attributed charisma, idealised influence and intellectual stimulation) are not empirically distinguishable. However, the transactional leadership scales come out as distinct factors. These results are yet to be interpreted in conjunction with confirmatory factor analysis and the partial least squares analysis.

To further understand the nature and importance of leadership in IS projects, 18 senior IS executives of the participating organisations were recently interviewed. These interviews are now being content analysed.

\section{CONCLUSIONS}

The results of the study indicate that:

- There is a significant difference in the leadership styles of more and less successful project managers as perceived by themselves, their subordinates and their senior managers. In other words, leadership and leadership style significantly influence the project outcome.

- More successful managers exhibit significantly more of transformational leadership characteristics, namely, attributed charisma, idealised influence, intellectual stimulation and individualised consideration. They also exhibit more of technical leadership characteristics, such as the ability to fulfil subordinates' desire for autonomy, implement change, preventing organisational bureaucracy, encourage champions, and facilitate career development. 
- The Bass \& Avolio's leadership model is significantly successful in differentiating between more and less successful IS managers based on their leadership behaviour and adequately capturing the key behaviours of successful IS project managers. The contingent reward behaviour seems to be more important in the context of an IS project environment than some of the transformational leadership behaviours. The results also suggest that there are some other important characteristics of a successful IS or technical managers which are not covered by the model, such as the ones described in the study as technical leadership characteristics. The managers, their subordinates and their senior managers have rated technical leadership behaviours as important, if not more, than some or all of the transformational leadership behaviours.

- While the study recommends transformational leadership style to an IS manager to enhance leadership effectiveness, it has been rightly pointed out by the senior IS managers interviewed for this study that there is no one style which is effective in all projects and it should change depending on the specific situation. However, transformational leadership can be an underlying but flexible leadership style for enhanced effectiveness.

- The contingency factors considered in the study are well supported. A leader requires the back up of other critical success factors such as project mission, top management support and technical expertise to ensure success.

Thus, the study produces evidence that leadership is a critical success factor in an IS project environment and that the leadership skills and styles of the project manager significantly influence the outcome of IS projects. The research clearly indicates that those IS project managers who are charismatic, individually considerate, intellectually stimulating and inspiring are more likely to produce successful project outcomes.

\section{REFERENCES}

Abdel-Hamid, Tarek, K. M., Stuart, E. (1990) The Elusive Silver Lining: How We Fail to Learn from Software Development Failures, Sloan Management Review, 32(1), 39-48.

Anderson, S. D. (1992) Project Quality \& Project Managers, International Journal of Project Management, 10(3), 138-144.

Atwater, D. C. \& Bass, B. M. (1994) Transformational Leadership in Teams in Bass, B. M. \&

Avolio, B. J. (Eds.) Improving Organisational Effectiveness through Transformational Leadership, Sage Publications, California.

Bander, D. (1986) Building a Better Project Manager, Computerworld, 20(21), 69-78.

Bass, B. M. and Avolio, J. A. (1993) Transformational Leadership: A Response to Critiques, Leadership theory and research: Perspectives and directions, Academic Press Inc.

Bass, B. M. \& Avolio, B. J. (1989) (1991) Transformational Leadership Development : Manual for the Multi-Factor Leadership Questionnaire, Consulting Psychologists Press, California.

Bass, B. M. (1985). Leadership and Performance Beyond Expectations, Free Press, New York.

Bates, W. S. (1994) Strong Leadership Crucial, Computing Canada, 20(22), 32.

Beatty, C and Lee, G. (1992) Leadership among Middle Managers - An Exploration in the Context of Technological Change. Human Relations, 45 (9), 957-989.

Bloom, N. L. (1996) Select the Right IS Project Manager for Success, Personnel Journal, Jan 1996, 6-9.

Brown, S. (1994) Critical Success Factors in Information Technology Projects, Unpublished Minor Thesis for the Degree of Master of Engineering, RMIT, Melbourne.

Burns, J. M. (1978) Leadership, Harper \& Row, New York.

Carless, S. A. (1995) Transformational Leadership and Teams: An Examination of the Bass and

Kouzes- Posner Models. Unpublished doctoral dissertation, University of Melbourne.

Carter, N. (1988) The Project Manager: An Emerging Professional, Journal of Information Systems Management, 5(4), 8-14.

Cash, C. H. \& Fox, R. (1992) Elements of Successful Project Management, Journal of Systems Management, 43(9), 10-12.

Cleland, D. I. (1995) Leadership and the Project-Management Body of Knowledge, International Journal of Project Management, 13(2), 83-88.

Conners, E. (1995), MIS 100, Strategic Publishing Group, Sydney.

Deutsch, M. S. (1991) An Exploratory Analysis Relating the Software Project Management

Process to Process Success, IEEE Transactions on Engineering Management, 38(4), 365-375.

Geaney, M. M. (1995) The Right Skills for the Job, Computing Canada, 21(24), 52. 
Howell, J. M. and Higgins, L. A. (1990). Champions of Technological Innovation, Administrative Science Quarterly, 35 (2), 317-341.

Kapur, G. (1989) Running in Crisis Mode?, Computerworld, 23(16), 89-93.

Keller, R. T.(1995) Transformational Leaders Make a Difference, Research Technology Management, 38(3), 41-44.

Keller, R. T. (1992) Transformational Leadership and the Performance of Research and Development Project Groups, Journal of Management, 18(3), 481-501.

Kennedy, L. (Ed.) (1996). The Software 50. Summer, 1996, IDG Communications, St. Leonards.

Laudon K. \& Laudon J. (1990) Management Information Systems: A Contemporary Perspective, Maxwell Maxmillan.

Palmer, C. \& Ottley, S. (1990) From Potential to Reality, A Report by the British Computer Society Task Group on Hybrids, January 1990.

Parry, K. W. \& Sarros, J. C. (1994) Transformational leadership in Australia: How different from the United States?. Unpublished manuscript.

Pinto, J. K. \& Prescott, J. E. (1988) Variations in Critical Success factors over the Stages in the Project Life Cycle, Journal of Management, 14(1), 5-18.

Pinto, J. K. \& Slevin, D. P. (1992) Project Implementation Profile, Xicom Inc., New York.

Pinto, J. K. \& Slevin, D. P. (1989) Critical Success Factors in R\&D Projects, Research Technology Management, Jan-Feb 1989, 31-35.

Pinto, J. K. \& Slevin, D. P. (1987) Critical Factors in Successful Project Implementation, IEEE Transactions on engineering Management, EM-34(1).

Phan D, Vogel D \& Nunamaker J. (1988) The Search for Perfect Project Management, Computerworld, September 1988, 95-100.

Pulk, B. E. (1990) Improving Software Project Management, Journal of Systems \& Software, 13(3), 231-235.

Rahn, D. (1987) Projects Need 'Right Stuff', Computerworld, 21(14), 79-80.

Rosenbaum, B. L. (1991) Leading today's technical professional, Training and Development, 45 (10), 55-66.

Sauer, C. (1993) Why Information Systems Fail: A Case Study Approach, Alfred Waller, UK.

Slevin, D.P. and Pinto, J.K. (1986). The Project Implementation Profile: New Tool for Project Managers, Project Management Journal, September 1986. 57-70.

Steeh, C. (1981). Trends in Non-Response Rates 1952-1979, Public Opinion Quarterly, 45, 40-57.

Thite, M. R. (1997) Managerial Skills in Technical Professionals- An Exploration of IT Project Leadership. In Barta, B. et al. (Eds.) The Place of Information Technology in Management and Business Education, London: Chapman \& Hall.

Wateridge, J. (1995) IT Projects: A Basis for Success, International Journal of Project Management, 13(3), 169-172.

Weinberg, G. M. (1986) Becoming a Technical Leader, Dorset, New York. 